\title{
Self Efficacy, Conscientiousness dan Employee Engagement
}

\section{Self Efficacy, Conscientiousness and Employee Engagement}

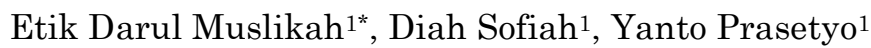 \\ Fakultas Psikologi Universitas 17 Agustus 1945 Surabaya \\ *etikdarul@gmail.com
}

\begin{abstract}
Abstrak
Penelitian ini bertujuan untuk mengetahui hubungan self efficacy dan conscientiousness dengan employee engagement. Hipotesis dalam penelitian ialah ada hubungan antara self efficacy dan conscientiousness dengan employee engagement. Penelitian ini termasuk dalam jenis penelitian kuantitatif noneksprimen. Penelitian ini mengambil lokasi di Rumah Sakit St. Vincentius a Paulo Surabaya. Adapun yang menjadi subjek penelitian adalah karyawan ataupun karyawati dari semua bagian yang berada di Rumah Sakit St. Vincentius a Paulo. Diketahui bahwa populasi yang berada di Rumah Sakit St. Vincentius a Paulo adalah 1255 karyawan. Populasi ini memiliki karakteristik yaitu karyawan tingkat pelaksana dan berstatus sebagai karyawan tetap. Dalam menentukan jumlah subyek, peneliti menggunakan penentuan subyek menurut pendapat Slovin, maka ditentukanlah subyek penelitian yang akan digali datanya dalam penelitian ini sebanyak 95 orang. Perhitungan pada penelitian ini menggunakan teknik analisis regresi yang diolah dengan program Statistic Package for Social Science for windows (SPSS) versi 22.0. Hasil analisis menunjukkan nilai koefisien korelasi $(\mathrm{r})$ sebesar 0.815 dengan taraf signifikansi $(\mathrm{p}=0.000)$. Hasil dari penelitian ini ialah ada hubungan antara self efficacy dan conscientiousness dengan employee engagement, sehingga hipotesis yang diajukan dinyatakan diterima.
\end{abstract}

Kata kunci: Self Efficacy, Conscientiousness, Employee engagement

\begin{abstract}
This study aims to find out the correlation between self efficacy and conscientiousness with employee engagement. The hypothesis in this study is that there is a relationship between self efficacy and conscientiousness with employee engagement. This research is included in the type of quantitative nonexperimental research. This research took place in St. Hospital. Vincentius a Paulo Surabaya. As for the subjects of the study were employees or employees of all sections in the St. Hospital. Vincentius a Paulo. It is known that the population residing in the St. Vincentius a Paulo is 1255 employees. This population has the characteristics of executing-level employees and permanent employees. In determining the number of subjects, researchers used the determination of subjects according to Slovin's opinion, then determined the research subjects to be extracted data in this study as many as 95 people. The analysis shows the correlation coefficient $(r)$ of 0.815 with a significance level $(p=0.000)$. The results of this study are that there is a correlation between self efficacy and conscientiousness with employee engagement, so the hypothesis submitted is accepted.
\end{abstract}

Key words : Self Efficacy, Conscientiousness, Employee engagement 


\section{Pendahuluan}

Pentingnya keberadaan sumber daya manusia yang handal dalam sebuah organisasi atau perusahaan pada era globalisasi ini menuntut adanya karyawan dengan produktivitas tinggi. Organisasi membutuhkan karyawan yang proaktif, memiliki inisiatif tinggi dan mempunyai tanggung jawab penuh terhadap perkembangan perusahaan dan karir. Selain itu, perusahaan juga membutuhkan karyawankaryawan yang energik dan berdedikasi, yaitu karyawan yang memiliki engagement di dalam menjalani pekerjaannya (Bakker dan Leiter, 2010). Engagement sering kali dipandang sebagai kunci untuk mengangkat organisasi ke tingkat yang lebih tinggi dalam perusahaan untuk menjalankan dan mencapai bisnis yang sukses.

Berlawanan dengan hal tersebut, banyak ditemukan fenomena keluarnya karyawan secara signifikan. Sejak jaman revolusi industri dimulai, fenomena keluarnya karyawan sudah menjadi hal yang biasa. Tidak ada ikatan apapun yang dapat memastikan hubungan kekaryawanan dapat bertahan sampai karyawan resmi pensiun (Adryanto, 2014). Hal ini terbukti dengan Global Work Force Study 2012 yang mengikutkan 29 negara termasuk Indonesia dengan total responden sebanyak 32.000 karyawan. Dua pertiga (65\%) dari 32.000 karyawan, tidak memiliki engagement yang tinggi terhadap organisasinya.

Fakta lainnya yaitu dari Gallup Worlwide yang melakukan survei pada tahun 2013 terhadap 73.000 responden dari 141 negara di dunia, termasuk Indonesia. Hasil riset Gallup itu menunjukkan hanya 8\% karyawan di Indonesia yang benar-benar memiliki level engagement yang tinggi, komitmen dan motivasi kuat dengan pekerjaannya. Sisanya, atau $92 \%$ hanya melakukan pekerjaannya dengan sekedarnya.

Kehilangan karyawan berprestasi tinggi dan karyawan dengan keahlian khusus sudah menjadi masalah yang perlu diwaspadai oleh industri, termasuk di Indonesia. Sejalan dengan fenomena di atas, survei Compdata's 2013 yang melibatkan 40.000 organisasi dari beberapa negara sebagai obyek penelitian juga menerangkan hal serupa. Hasil penelitian menunjukkan bahwa tingkat turnover di sektor kesehatan sebesar $16.8 \%$, merupakan tertinggi ketiga diantara 8 sektor industri yang diteliti. Menurut Adryanto (2016), apabila tingkat turnover lebih dari 10\% maka dinilai mengkhawatirkan. Tingginya angka turnover merupakan salah satu indikasi paling kuat untuk melihat rendahnya employee engagement. (Nurwulandari \& Suwatno, 2017).

Menurut Adryanto (2016), engagement adalah tingkat komitmen karyawan terhadap suatu atau seseorang di dalam organisasi yang menunjukkan sejauh mana karyawan bekerja keras serta seberapa lama karyawan tetap bergabung dengan organisasi sebagai konsekuensi dari komitmen yang dibuat. Engagement diartikan sebagai status keterikatan seorang karyawan terhadap lingkungan kerja atau perusahaan tempatnya bekerja, artinya kondisi dimana seorang karyawan merasa mempunyai ikatan yang sangat spesial dengan lingkungan kerjanya. Oleh karena itu, karyawan dengan sukarela akan melakukan apapun untuk kemajuan perusahaannya dengan terus berkontribusi secara optimal. Schaufeli \& Bakker (2006) mendefinisikan engagement sebagai suatu hal yang positif, memuaskan, sikap pandang yang berkaitan dengan pekerjaan yang ditandai oleh vigor, dedication dan absorption.

Adanya engagement karyawan dipengaruhi oleh banyak faktor, secara umum yaitu faktor internal dan faktor eksternal. Menurut Maslach dan Leiter (1997), salah satu ciri karyawan yang memiliki engagement adalah adanya self efficacy. Hal ini didukung dengan penelitian yang dilakukan oleh Luthans, dkk (2008) yang menyatakan bahwa self efficacy memiliki hubungan yang signifikan terhadap employee engagement. Sebagaimana hasil penelitian Niu (2010) menyatakan bahwa karyawan yang memiliki self efficacy tinggi berkomitmen terhadap pekerjaannya. Komitmen merupakan salah satu aspek dari employee engagement.

Selain self efficacy, terdapat faktor lain dalam diri individu yang dapat mempengaruhi seberapa engaged orang tersebut terhadap suatu pekerjaan dan perusahaan, yaitu kepribadian. Setelah beberapa dekade, cabang psikologi kepribadian memperoleh pendekatan taksonomi kepribadian yang dapat diterima secara umum, yaitu big five personality. Big five personality adalah kepribadian individual yang tersusun dalam lima buah domain kepribadian yang telah dibentuk dengan menggunakan analisis faktor. Lima dimensi pada big five personality memiliki hubungan langsung dengan faktor keturunan biologis.

Salah satu trait yang terdapat pada big five personality yang diprediksi dapat mempengaruhi engagement seseorang ialah conscientiousness. Conscientiousness merupakan perilaku tugas dan arah tujuan, menilai kemampuan individu dalam organisasi, baik mengenai ketekunan dan motivasi, dan secara sosial membutuhkan impuls kontrol. Individu dengan tipe kepribadian conscientiousness menunjukkan ciri rasional dan berfikir bahwa diri mereka mempunyai kompetensi yang tinggi (competence). Sebagian dari kesuksesan mereka berasal dari kemampuan mereka dalam organisasi yang baik serta keteraturan yang tinggi (order). Kedua hal ini yang membuat mereka bekerja dengan efisien. 
Individu yang conscientiousness memegang teguh tugas (dutifulness), memiliki kebutuhan akan pencapaian prestasi yang tinggi (achievement striving), dan menggapai kesempurnaan dalam segala sesuatu hal yang mereka lakukan demi pencapaian prestasi, memiliki displin diri yang tinggi sehingga mampu mencapai tujuan mereka (self-discipline), umumnya menunjukkan ciri pertimbangan (deliberation), berpikir penuh dengan kehati-hatian sebelum bertindak dan membuat rencana di awal bukan dengan cara yang tiba-tiba.

Kedua faktor yang telah dijelaskan di atas, yaitu self efficacy dan conscientiousness menjadi hal yang penting untuk prediktor employee engagement. Ketika keyakinan seseorang terhadap kemampuannya dalam menghadapi berbagai masalah atau tantangan tinggi diimbangi dengan kepribadian conscientiousness, maka semakin meningkat engagement karyawan kepada perusahaan tempat bekerja. Oleh karena itu, peneliti tertarik untuk meneliti employee engagement, self efficacy dan conscientiousness.

\section{Metode Penelitian}

Penelitian ini mengambil lokasi di Rumah Sakit St. Vincentius a Paulo Surabaya. Adapun yang menjadi subjek penelitian adalah karyawan ataupun karyawati dari semua bagian yang berada di Rumah Sakit St. Vincentius a Paulo. Diketahui bahwa populasi yang berada di Rumah Sakit St. Vincentius a Paulo adalah 1255 karyawan. Populasi ini memiliki karakteristik yaitu karyawan tingkat pelaksana dan berstatus sebagai karyawan tetap. Dalam menentukan jumlah subyek, peneliti menggunakan penentuan subyek menurut pendapat Slovin, maka ditentukanlah subyek penelitian yang akan digali datanya dalam penelitian ini sebanyak 95 orang. Rancangan penelitian ini menggunakan jenis penelitian korelasi. Hal ini dikarenakan tema yang diambil merupakan penelitian untuk mengetahui hubungan dan tingkat hubungan antara dua atau lebih variable. Tujuan penelitian korelasional menurut Suryabrata (dalam Abidin, 2010) adalah untuk mendeteksi sejauh mana variasi-variasi pada suatu faktor berkaitan dengan variasi-variasi pada satu atau lebih faktor lain berdasarkan pada koefisien korelasi.

Penelitian ini termasuk dalam jenis penelitian kuantitatif noneksprimen. Dimana penelitian ini mencari hubungan antara variabel satu dengan variabel yang lainnya. Pada penelitian ini terdapat tiga variabel yang terlibat yaitu self efficacy, conscientiousness dan employee engagement. Dimana yang berperan sebagai variabel bebas adalah self efficacy dan conscientiousness dan yang berperan sebagai variabel tergantung adalah employee engagement.

Definisi operasional dari employee engagement ialah suatu hal yang berkaitan dengan pekerjaan yang dilakukan karyawan terhadap perusahaan atau organisasi tempatnya bekerja, yang ditandai dengan kesungguhan dan ketekunan dalam bekerja, memiliki kebanggaan terhadap pekerjaannya, menyukai tantangan dalam pekerjaannya, dan penuh dengan konsentrasi dalam bekerja. Self efficacy merupakan keyakinan individu mengenai kemampuan dirinya dalam melakukan tugas, mengatasi hambatan dan melakukan tindakan yang diperlukan untuk mencapai hasil tertentu. Conscientiousness merupakan perilaku individu-individu yang cenderung menjadi pekerja keras, dapat dipercaya, terorganisasi, selfdirected, tepat, ambisius, kasar, dan keras hati.

Penelitian ini terdiri dari tahap persiapan, tahap pelaksanaan, dan tahap analisa data. Pada tahap persiapan penelitian dilakukan melalui beberapa tahap, yaitu membuat alat ukur skala self efficacy, skala conscientiousness dan skala employee engagement. Pada tahap pelaksanaan dilakukan dengan membagikan skala pada 95 karyawan yang bekerja di Rumah Sakit St. Vincentius a Paulo, kemudian dilakukan uji validitas dan reliabilitas menggunakan IBM SPSS versi 21.0 for Windows. Sesuai dengan tujuan penelitian ini yaitu untuk melihat hubungan dan pengaruh antara self efficacy dan conscientiousness dengan employee engagement, maka untuk perhitungannya menggunakan teknik analisis regresi yang diolah dengan program Statistic Package for Social Science for windows (SPSS) versi 22.0. Penelitian ini juga dapat melihat pengaruh dari masing-masing variabel bebas terhadap variabel terikat dan pengaruh kedua variabel bebas secara bersama-sama terhadap variabel terikat.

\section{Hasil Penelitian}

Hasil analisis menunjukkan bahwa ada korelasi positif yang signifikan antara self efficacy dan employee engagement $(\mathrm{rx} 1 \mathrm{y}=0,792 ; \mathrm{p}=0,000)$. Hal tersebut dapat diartikan bahwa semakin tinggi self efficacy, maka semakin tinggi employee engagement. Hasil analisis berikutnya menunjukkan bahwa ada korelasi positif yang signifikan antara conscientiousness dan employee engagement $(\mathrm{rxy}=0,335 ; \mathrm{p}=$ 0,021), artinya semakin tinggi conscientiousness, maka semakin tinggi pula employee engagement. Hasil analisis ketiga menunjukkan bahwa ada korelasi positif yang signifikan antara self efficacy dan conscientiousness dengan employee engagement $((\mathrm{r}=815 ; \mathrm{p}=0,000)$, dapat diartikan bahwa semakin tinggi self efficacy dan conscientiousness, maka semakin tinggi engagement karyawan. 
Sumbangan efektif dari variabel self efficacy terhadap employee engagement sebesar $(\mathrm{r} 2=0.627)$, artinya sebesar $62.7 \%$ self efficacy diprediksi dapat memiliki pengaruh terhadap employee engagement. Sumbangan efektif dari conscientiousness terhadap employee engagement sebesar ( $\mathrm{r} 2=0.112$ ), artinya sebesar $11.2 \%$ conscientiousness dimungkinkan memiliki pengaruh terhadap employee engagement. Sedangkan sumbangan efektif jika self efficacy dan conscientiousness terhadap employee engagement yaitu sebesar ( $\mathrm{r} 2=0.664$ ), artinya sebesar $66.4 \%$ self efficacy dan conscientiousness secara bersama mungkin memiliki pengaruh terhadap employee engagement.

\section{Pembahasan}

Hipotesis dalam penelitian ini dapat diterima. Hasil pengujian hipotesis menunjukkan bahwa ada korelasi antara self efficacy dan conscientiousness dengan engagement karyawan. Ini berarti bahwa semakin tinggi skor self efficacy dan conscientiousness akan semakin tinggi engagement karyawan. Seperti yang telah dijelaskan sebelumnya, bahwa employee engagement dapat dipengaruhi oleh banyak faktor, baik internal maupun eksternal. Salah satu faktor yang dapat menjadi prediktor employee engagement ialah self efficacy. Orang yang memiliki self efficacy tinggi artinya orang tersebut yakin dengan kemampuan yang dimiliki ketika menghadapi masalah. Hal ini juga sejalan dengan pendapat Prieto, Salanova dan Martinez (2009) yang mengemukakan bahwa self efficacy membantu seseorang untuk lebih termotivasi ketika berhadapan dengan halangan dan kesulitan. Hal ini didukung dengan penelitian yang dilakukan oleh Luthans, dkk (2008) yang menyatakan bahwa efikasi diri memiliki hubungan yang signifikan terhadap employee engagement.

Luthans, dkk. (2002) mendefinisikan self efficacy sebagai keyakinan seseorang atau keyakinan tentang kemampuannya untuk mengarahkan motivasi, sumber kognisi, dan melakukan sejumlah tindakan yang diperlukan untuk mencapai keberhasilan dalam melaksanakan tugas dalam konteks tertentu. Orang yang memiliki self efficacy memiliki karakteristik antara lain mampu menetapkan target tinggi untuk diri mereka sendiri dan melakukan tugas-tugas sulit, menerima tantangan secara bahagia dan terbuka memiliki motivasi diri yang tinggi, melakukan berbagai upaya untuk mencapai target yang telah dibuat dan gigih ketika menghadapi hambatan. Kelima karakteristik ini, orang-orang dengan self efficacy yang tinggi akan dapat mengembangkan diri secara mandiri dan mampu menjalankan tugasnya secara efektif. Orang yang memiliki self efficacy yang tinggi akan dapat menetapkan tujuan dan memilih tugas-tugas sulit untuk diri mereka sendiri.

Menurut McCrae \& Costa (Cervone \& Pervin, 2012) conscientiousness didefinisikan sebagai perilaku tugas dan arah tujuan, menilai kemampuan individu dalam organisasi, baik mengenai ketekunan dan motivasi, dan secara sosial membutuhkan impuls kontrol. Secara konkrit, conscientiousness merupakan perilaku individu-individu yang cenderung menjadi pekerja keras, dapat dipercaya, terorganisasi, self directed, tepat, ambisius, kasar, dan keras hati. Hal tersebut sejalan dengan penelitian yang dilakukan oleh Noeraziz (2017) yang berjudul Hubungan antara kepribadian dengan work engagement pada dosen di Universitas Airlangga. Hasilnya menunjukkan bahwa aspek kepribadian conscientiousness memiliki hubungan dengan work engagement $(\mathrm{r}=387)$. Orang yang memiliki kepribadian conscientiousness akan dengan penuh energi melakukan pekerjaannya. Pribadi tersebut memiliki rencana yang teratur dan ambisius dalam penyelesaian tugas. Kemampuan-kemampuan tersebut akan berkorelasi dengan engagement, melalui peningkatan aspek kekuatan, penyerapan dan dedikasi.

Berdasarkan hasil penelitian yang telah dilakukan, dapat dikatakan bahwa apabila individu memiliki efikasi diri yang tinggi, artinya yakin dengan kemampuan yang dimiliki diimbangi dengan kepribadian yang conscientious yaitu yang teratur, penuh ambisi, ingin melakukan pekerjaan dengan sempurna dan pekerja keras, maka individu tersebut akan engaged dengan pekerjaan dan perusahaan tempat ia bekerja.

\section{Kesimpulan}

Berdasarkan penelitian yang telah dilakukan tentang hubungan self efficacy dan conscientiousness dengan employee engagement, maka dapat disimpulkan: terdapat hubungan positif dan signifikan antara self efficacy dan conscientiousness dengan employee engagement. Self efficacy dan conscientiousness berpengaruh positif terhadap employee engagement. Semakin tinggi self efficacy dan conscientiousness, maka semakin tinggi pula engagement karyawan. Self efficacy diartikan sebagai keyakinan seseorang atau keyakinan tentang kemampuannya untuk mengarahkan motivasi, sumber kognisi, dan melakukan sejumlah tindakan yang diperlukan untuk mencapai keberhasilan dalam melaksanakan tugas dalam konteks tertentu. Orang yang memiliki self efficacy memiliki karakteristik antara lain mampu menetapkan target tinggi untuk diri mereka sendiri dan melakukan tugas-tugas sulit, menerima 
tantangan secara bahagia dan terbuka memiliki motivasi diri yang tinggi, melakukan berbagai upaya untuk mencapai target yang telah dibuat dan gigih ketika menghadapi hambatan. Conscientiousness adalah menilai tingkat organisasi, ketekunan, kontrol, dan motivasi dalam perilaku yang diarahkan pada tujuan. Conscientiousness tinggi mengidentifikasi individu yang cenderung terorganisir, dapat diandalkan, pekerja keras, mandiri, tepat waktu, teliti, ambisius, dan gigih. Karakteristik perilaku ini akan terkait dengan peningkatan engagement karyawan melalui peningkatan aspek semangat, penyerapan dan dedikasi.

\section{Daftar Pustaka}

Adryanto, Michael. 2016. Tips \& Tricks Engaging Talents: meningkatkan kontribusi produktif karyawan secara strategis, etis. Jakarta: Prasetiya Mulya Publishing.

Alwisol. 2009. Psikologi Kepribadian. Malang: UMM Press.

Bakker, Arnold. B., Leiter, Michael. P. 2010. Work Engagement: A Handbook of Essential Theory and Research. New York: Psychology Press.

Bakker, A. B., Schaufeli, W. B., \& Leiter, M. P. 2006. Work engagement: An emerging concept in occupational health psychology. Journal of Work and Stress, 22 (3), 187-200.

Bandura, A. 1986. Social Cognition Theory. Prentice Inc. Englewood Cliffs, N.J.

Coffman, C. 2002. Building A Highly

Engaged Workforce: How Great Managers Inspire Virtuoso Performance. Gallup Management Journal. http://gmj.gallup.com. Diunduh pada tanggal 21 Februari 2017

Eisenberger, R., Fasolo, P., \& Davis-LaMastro, V. 1990. Perceived organizational support and employee diligence, commitment, and innovation. Journal of Applied Psychology. Vol 75, 51-59.

Feist \& Feist.2008. Theories of Personality (7th, Seventh Edition). New York. USA : McGraw-Hill.

Feist, Jess dan Feist, Gregory. 2010. Teori Kepribadian. Buku 2. Jakarta: Salemba Humanika

Greenberg, Gerald dan Baron, Robert A. 2003. Behavior in Organization: Understanding and Managing the Human Side of Work. 3th ed. Boston: Allyn and Bacon.

Hadi, C \& Indrianti, R. 2012. Hubungan Antara Modal Psikologis Dengan Katerikatan Kerja Pada Perawat di Instalasi Rawat Inap Rumah Sakit Jiwa Menur Surabaya. Jurnal Psikologi Industri dan Organisasi. Vol. 1 No.02, Juni 2012.

Hadi, Sutrisno. 2000. Metodologi Penelitian. Yogyakarta: Andi Yogyakarta.

Hall, Calvin S.\& Gardner Lindzey. 1993. Teori-Teori Psikodinamik (Klinis) Terjemahan Supratiknya.Yogyakarta: Kanisius.

Leiter \& Maslach C. 1997. The truth about burnout: How organization cause personal stress and what to do about it. USA: Jossey Bass

Luthans, F., dan Peterson, S. J., 2002, Employee engagement and manager self efficacy implications for managerial effectiveness and development. Journal of Management Development Vol.21 No.5, pp 376-387.

Niu, H. 2010. Erratum to \& ldquo; Investigating the effects of self efficacy on foodservice industry employees \& rsquo; career commitment. International Journal of hospitality Management, 29, 1336.

Nurwulandaari \& Suwatno. 2017. Pengaruh komunikasi Internal, Pengembangan Karir, Dan Penghargaan Intrinsik Terhadap Keterikatan Karyawan Pada Hotel Berbintang Di Kota Subang. Jurnal Ilmu Manajemen dan Bisnis Vol. 8 No.2.

Pervin, L. A., Cervone, D., \& John, O. P. (2005). Personality: Theory and Research (9th ed.). Hoboken, NJ: John Wiley \& Sons

Prasetyo, Y. 2016. Self efficacy, Kematangan Emosi dan Problem Focused Coping. Jurnal Persona.

Prieto, L.L., Salanova, M., \& Martinez, I. M. 2009. Exploring the power of self efficacy at work: Some empirical studies from the social cognitive perspective. Dissertation. Universitat Jaume I of Castellon.

Rhoades, L. \& Eisenberger, R. 2002. Perceived organizational support: A review of literature. Journal of Applied Psychology Vol. 87. 698-714.

Robinson, D., Perryman, S \& Hayday, S. 2004. The Drivers of Employee Engagement. http://www.wellbeing4business.co.uk/docs/Article\%20-\%20Engagement\%20research.pdf. Diunduh pada tanggal 25 Februari 2017.

Saks, A.M. 2006. Antecedents And Consequences Of Employee Engagement. Journal of Managerial Psychology Vol. 21 No. 7, 2006 
Shannock, Linda, Rhoades, Eisenberger Robert. 2006. When Supervisor Feel Supported : Relationship

With Subordinates Perceived Supervisor Support, Perceived Organizational Support and Performance. Journal of Applied Psychology. Vol. 91,. No. 3,689-695

Singarimbun, M dan Sofian Effendi. 2008. Metode Penelitian Survei. Jakarta: LP3ES

Solso, Robert L. dkk. 2007. Psikologi Kognitif. Jakarta : Erlangga.

Sugiyono. 2010. Metode Penelitian Kuantitatif Kualitatif \& RND. Bandung: Alfabeta

Suharman. 2005. Psikologi Kognitif. Jakarta: Aneka Karyacipta

Tanudjaja, RM. 2013. Hubungan Antara Konflik Keluarga-Kerja, Makna Kerja Sebagai Panggilan, dan Persepsi Terhadap Dukungan Organisasional Dengan Keterikatan Kerja Pada Guru. Jurnal Calyptra. Vol 2 No. 1, Maret 2013 